\title{
Teknik koleksi dan analisa cairan serebrospinal pada hewan kecil
}

\author{
Diah Pawitri $^{1,2, *}$, Deon Wibatsu Kristiawan ${ }^{3}$ \\ ${ }^{1}$ PDHB drh Cucu K. Sajuthi dkk., Jakarta \\ ${ }^{2}$ Klinik Hewan Vetnic Care, Bekasi \\ ${ }^{3}$ Program Pendidikan Profesi Dokter Hewan, Fakultas Kedokteran Hewan, Institut Pertanian Bogor, Bogor
}

\begin{abstract}
ABSTRAK: Cairan serebrospinal (Cerebrospinal Fluid/CSF) terdapat pada otak dan sumsum tulang belakang yang dilapisi oleh lapisan meninges. Penyakit yang terjadi pada daerah ini dapat menyebabkan perubahan karakteristik padacairan cerebrospinal. Analisa CSF merupakan bagian dari evaluasi diagnostik hewan yang memiliki indikasi adanya gangguan neurologik terutama seperti meningitis, ensefalitis dan myelitis yang memengaruhi sistem syaraf pusat, meninges dan sekitarnya, serta akar syaraf. Cairan serebrospinal dapat dikoleksi dengan metode atlanto-occipital cistern puncture dan lumbar puncture. Hewan diberikan anastesi general dan dibaringkan sternal atau lateral recumbency untuk memudahkan proses koleksi CSF. Cairan serebrospinal dapat di analisa melalui tampilan cairan, biokimia dan sitologi. Pengetahuan mengenahi teknik pengambilan CSF diperlukan untuk meminimalkan resiko cedera syaraf dan hal yang berkaitan dengan metodenya secara singkat dibahas dalam tulisan ini.

\section{Kata kunci:}

cairan serebrospinal, gangguan neurologik,hewan kecil
\end{abstract}

\section{PENDAHULUAN}

Cairan serebrospinal (Cerebrospnal Fluid/CSF) terdapat pada otak dan sumsum tulang belakang yang dilapisi meninges. Penyakit pada daerah ini dapat menyebabkan perubahan karakteristik CSF (Lowrie \& James 2011). Pengambilan CSF dilakukan dari atlanto ocipital cysternapuncture atau lumbal puncture (Scott 1997). Analisa CSF diperlukan jika suatu penyakit diduga berhubungan dengan peradangan pada sistem saraf pusat (CNS) seperti meningitis, encefalitis, dan myelitis (Lowrie \& James 2011). Secara umum kontra indikasi untuk peradangan CNS adalah sama dengan kontra indikasi pada general anastesi. Kontra indikasi lain yaitu instabilitas vertebrae cervicalis (kongenital atau trauma), fraktur atau luksasio struktur anatomi area tusukan, peningkatan tekanan intra kranial (perpindahan tekanan dapat menyebabkan herniasi), infeksi, trauma jaringan lunak area tusukan, serta hernia foramen magnus.

\section{MATERI DAN METODE}

Peralatan (Seguin 2001): Peralatan yang perlu disiapkan berupa jarum spinal steril $20 \mathrm{G}$ (anjing besar) atau22 $\mathrm{G}$ (anjing kecil dan kucing), tabung steril, sarung tangan steril.

Penanganan hewan (Seguin 2001): Anastesi general dilakukan sebelum koleksi CSF dilakukan. Hewan dibaringkan di pinggir meja. Posisilateral recumbencylebih disarankan karena tidak diperlukan syringe untuk koleksi. Posisiright lateral recumbency untuk operator pengguna tangan kanan dan left lateral recumbency untuk pengguna tangan kiri. Area yang akan ditusuk dicukur dan didesinfeksi dengan alkohol $70 \%$ dan povidone iodine $10 \%$.

Teknik atlanto-ocipital cistern puncture (Seguin 2001): Metode ini dilakukan dengan cara menekuk kepala bagian ventral sehingga tulang belakang paralel dengan meja dan posisi kepala $90^{\circ}$ terhadap sumbu tubuh (Gambar 1). Jarum posisi tegak lurus dimasukkan pada himpitan 2 garis imajiner antara midline dengan batas kranial alae atlantis kanan dan kiri. Jarum dimasukkan secara perlahan dan styletdilepaskan untuk melihat CSF mengalir keluar.
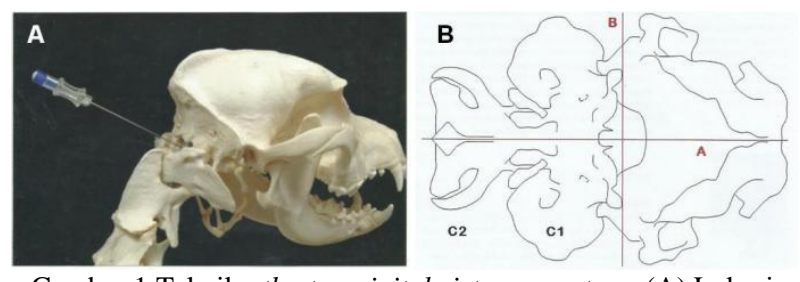

Gambar 1 Teknik atlanto-ocipital cistern puncture. (A) Lokasi penempatan jarum spinal, (B) Lokasi himpitan garis imajiner A (merah; midline) dan B (merah; batas kranial alae atlantis)

Hambatan sedikit berkurang saat jarum memasuki membran dorsal atlanto-occipital dan ruang sub arachnoid. Jarum digerakkan menuju kranial atau kaudal jika bagian ujung terkena tulang. Jika didapatkan darah segar, maka jarum ditarik keluar dan prosedur diulang dari awal. Kontaminasi

Diterima:18-07-2019 | Direvisi: 18-08-2019 | Disetujui:25-08-2019 (c) 2019 CC-BY-SA. Ini adalah artikel Open Access yang didistribusikan berdasarkan ketentuan dari Creative Commons Attribution ShareAlike 4.0 International License (https://creativecommons.org/licenses/by-sa/4.0/). 
sedikit darah masih dapat diabaikan. Cairan akan menetes ke dalam tabung hingga volume yang didapatkan cukup untuk analisa. Aspirasi menggunakan syringe dapat menimbulkan pendarahan. Jarum ditarik keluar dan biarkan hewan bangun dari pengaruh anastesi.

Teknik lumbar puncture (Seguin 2001): Metode ini dilakukan dengan menekuk tulang panggul menuju cranial. Lokasi tusukan pada ruang intra-vertebral L5-L6 atau L6L7 pada anjing serta celah lumbo-sacral pada kucing (Gambar 2). Jarum dengan sudut $20^{\circ}$ terhadap sumbu tubuh namun tetap pada midsagittal dengan arah jarum paralel terhadap prosesus spinosus. Prosedur dilakukan kembali pada ruang intervertebral cranial pada L4-L5 jika CSF sulit didapatkan. Penetrasi jarum pada ligamen interarkuata dapat terasa. Sumsum yang tertusuk jarum dapat menyebabkan refleks pada ekstrimitas. Umumnya bagian lumbar lebih sulit dimasuki jarum dan CSF lebih lambat menetes.
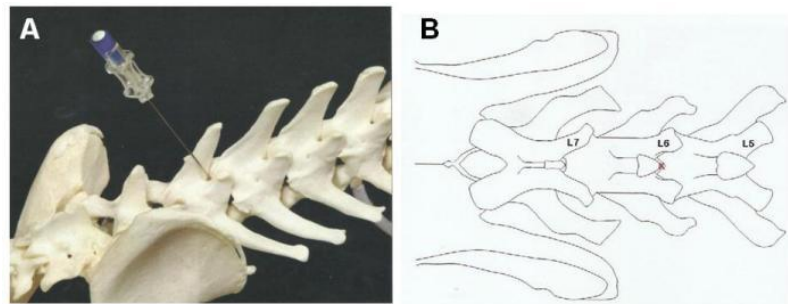

Gambar 2 Teknik lumbar puncture. (A) Lokasi penempatan jarum spinal, dan (B) Lokasi penempatan jarum spinal di antara os vertebrae-lumbalis 5 dan 6

Penanganan dan analisi sampel (Seguin 2001): Analisis sebaiknya dilakukan dalam 30 menit pascakoleksi, meskipun pemeriksaan hingga 4-6 jam tidak mempengaruhi hasil interpertasi secara signifikan. Penyimpanan CSF pada suhu $4^{\circ} \mathrm{C}$ tidak merubah konsentrasi protein dan total perhitungan sel dalam 48 jam. Jika analisis tidak dapat dengan segera dilakukan maka cairan CSF dibagi menjadi 2 tabung yaitu 1 tabung tanpa preservatif untuk perhitungan protein dan 1 tabung dengan preservatif untuk evaluasi sitologis. Preservatif yang dapat digunakan antara lain neutral buffered formalin (NBF) $10 \%$ dan serum autologous.

Intepretasi hasil analisa (Seguin 2001): Intepretsi dilakukan dengan melihat beberapa tanda:

1. Penampilan warna CSF (Gambar 3):

a. Normal bening dan tidak berwarna,

b. Merah cerah yang hilang setelah sentrifugasi menunjukkan baru terjadi hemoragi,

c. Kuning (xanthochromia) menunjukkan sudah lama terjadi hemoragi yang mengakibatkan peningkatan kadar bilirubin atau ikterus parah,

d. Cloudy/putih keruh berkabutsebagai efek pemberian steroid.

2. Kekeruhan terjadi karena sel pada CSF dalam jumlah banyak (>500 sel/ $\mu \mathrm{L})$
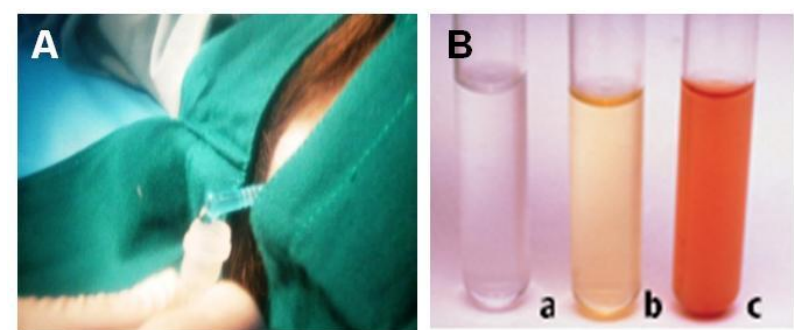

Gambar 3 Penanganan sampel. (A) Cairan CSF yang ditampung, dan (B) Beberapa warna CSF, antara lain: a. tidak berwarna; b. kuning; c merah cerah.

3. Peningkatan kadar albumin menunjukkan gangguan blood brain barrier, umum terjadi pada semua penyakit degenerasi syaraf tanpa inflamasi,demyelinisasi, neoplasia, dan infark.

4. Imunoglobulin yang meningkat mengindikasikan adanya produksi intratekal. Titer spesifik terhadap infeksi virus, fungi, dan protozoa dapat diuji lebih lanjut.

5. Biokimia lain seperti gula, kreatininkinase, dehidrogenase laktat pada CSF dapat diukur, namun nilai diagnostiknya saat ini masih dipertanyakan. Penurunan kadar gula dan peningkatan jumlah sel serta protein pada CSF menunjukkan adanya infeksi bakteri. Peningkatan lactic dehidrogenase terjadi pada penderita limfoma.

6. White Blood Cells (WBC) secara normal terkandung dalam CSF sekitar $<8$ sel $/ \mu \mathrm{L}$ dengan dominasi sel limfosit dan monosit. Penyakit inflamatori menyebabkan peningkatan jumlah WBC (pleocytosis) dan kadar protein. Peningkatan neutrofil menunjukkanadanya infeksi bakteri, monosit/limfosit mengindikasikan infeksi virus, peningkatan lebih kompleks mengindikasikan infeksi fungi atau protozoa. Dugaan infeksi bakteri pada CSF dapat dilakukan kultur untuk diagnosa lanjutan.

7. Kortikosteroid yang diberikan pada pasien dapat mengurangi perhitungan sel berinti, neutrofil dan limfosit, serta konsentrasi protein.

\section{SIMPULAN}

Cairan serebrospinal dikoleksi untuk penegakan diagnosa penyakit sistem saraf pusat, dapat dilakukan secaraatlantooccipital cistern puncture dan lumbar puncture pada hewan kecil dengan analisa tampilan, biokimia dan sitologi.

\section{- INFORMASI PENULIS}

Penulis untuk Korespondensi

*DP: Drh.diahp@gmail.com

Klinik Hewan Vetnic Care, Ruko Emerald, Blok UE No. 8, Sumerecon, Bekasi

\section{- PUSTAKA ACUAN}

Lowrie M, James A. 2011. Cerebrospinal fluid: Analysis and interpretation in small animals. In Practice. 33 (2):78-85.

Scott HW. 1997. Clinical technique spinal puncture. Waltham Focus. 7 (2): $10-12$

Seguin B. 2001. Cerebrospinal fluid collection and analysis in dogs and cats. Waltham Focus 11(4): 26-30 